\title{
Resource Planning as a Panacea for Successful Completion of Water Projects in Semi-Arid Areas in Machakos County, Kenya
}

\author{
Harrison Mbaluto Mutuku, Mumo Mueke, and Augustine Mwangi
}

\section{ABSTRACT}

This study aimed at establishing the influence of resource planning on successful completion of water projects in semi-arid areas in Kenya with a specific focus on Machakos County. The target population consisted of 648 representative beneficiaries of water projects in Machakos County, Water Management committee members, Sub-County water officers and Machakos County Local Coordinators who are involved in water projects in Machakos County. A sample of 241 respondents was selected using purposive and simple random sampling procedures. The study had a response rate of $70.5 \%$. Descriptive and inferential statistic was employed to analyze the quantitative data. From the simple linear regression conducted, the findings revealed resource Planning influences successful completion of water projects meaning that there was positive relationship between resource planning and successful completion of water projects in semi-Arid Areas. The study recommends the need for legislative authorities to increase statutory allocation to help enhance successful completion of water projects.

Keywords: Project Completion, Resource planning, Successful Completion, Semi-Arid areas, Water project.

\section{INTRODUCTION}

Resources is a collection of people, equipment's, places, money, or anything needed to achieve set objectives while resource planning is a chronological process of achieving organization's objectives by providing sufficient finance, machinery, manpower and materials [19].

According to [19] resource planning aids in creation and stabilization of the links between projects, teams, tasks, budget, and time. This is achieved by carefully estimating resources by utilization of expert judgment, focusing on alternative analysis, installing project management software, and implementing bottom-up estimation.

According to statistics, approximately $30 \%$ of the world's population lives in semi-arid areas of which $18.5 \%$ have no access to water. Resources planning for water projects have continue to be a global crisis since early 1960's to date. It is approximated that $35 \%$ of the global population have problem of water scarcity. Studies conducted globally have demonstrated that lack of resource planning in water projects is the key contributor to the high population of people who have no access to water.

Further, findings from these studies have demonstrated that due to lack of proper resource planning, there is inefficient estimation of manpower, money, machinery, and materials to execute water projects [20].

India is one of the countries in the world that receive high rainfall annually especially the areas of Mousinram and
Submitted : May 18, 2021

Published : June 08, 2021

ISSN: 2507-1076

DOI: $10.24018 /$ ejbmr.2021.6.3.890

Harrison Mbaluto Mutuku* MA Project Planning and Management Candidate, University of Nairobi, Kenya. (e-mail: mbalutonet ${ }^{@}$ gmail.com) Mumo Mueke

University of Nairobi, Kenya. (e-mail: mumomueke@yahoo.com) Augustine Mwangi University of Nairobi, Kenya. (e-mail: augmwa2002@gmail.com)
Cherrapunji. It receives approximately $4000 \quad \mathrm{~km}^{3}$ precipitation annually and the average flow of Indian's rivers per year is estimated as $1953 \mathrm{~km}^{3}$ but it is still one of the countries in the world that suffer from shortage of water during the non-rainy seasons almost every year. A study conducted by [17] on water resources in India demonstrated that lack of resource planning in terms of finance and machinery and pollution of both the point and non-point sources of water were the major contributors to the annual shortage of water. Evidently, resource planning is pivotal in ensuring successful completion of water projects by ensuring there is flow of water throughout the year.

Africa is characterized with an annual rainfall of 1,000 millimeters of which those regions that are closer to the equator receives more rainfall annually. Apart from rainfall, there are rivers, dams, lakes, and oceans which provide water for the population. Ironically, effective management of water project is still a mountain climb due to the effects of poor resource planning. There are many underlying factors that inhibit resource planning for water projects in Africa. Tanzania has a vast number of water resources and a significant number of major lakes and rivers, but 4 million people still have no access to water. There are many government programs in the land that aids in the supply of water to rural and urban set-ups. But over the years this government projects have seen faced many problems due to lack of effective resource planning of water projects. According to [3] there are many water projects in Tanzania though three-quarter of the projects have not achieved the 
desired objective. In their study, they concluded that resource planning was a vital tool in the success of water projects.

Subsequently in Kenya, there is practically $30 \%$ gab between available water and the demand of water. Although the Kenya's Water Resource Management (KWRM) is working around the clock to sustain water supply in the region there is still a wide gap between the available water and its demand. There are many water projects that are incomplete due to vandalism, poor management, and poor resource planning and government policy among others. The same case is witnessed in Machakos County which is as semi-arid region. Although there is resource planning of water projects, there still exist shortcomings that hinder the resource planning of water projects in Machakos County, Kenya [13]. It is against this background that this study intends to fill the knowledge gap on influence of resource planning in the successful completion of water projects in semi-arid areas in Kenya: a case of Machakos County.

The objective of this study was therefore to establish influence of resource planning as a panacea in successful completion of water projects in semi-arid areas in Machakos County.

\section{LITERATURE REVIEW}

In order to address water scarcity challenges in semi-arid areas, participation of multiple stakeholders is required. Apart from this, effective resource planning of the water project plays a significant role in the eradication of water scarcity problem in semi-arid areas. Different organization like Center of Excellence on Water Security (AQUASEC) utilize resource planning as one of ideal methods of linking with other organizations throughout the world in quest of trying to solve water scarcity challenge in semi-arid areas [10]. Evidently, with effective resource planning of water projects, the problem of water shortage will be reduced if not eradicated completely.

According to research conducted by [18] challenges engendered by lack of sustainability in water projects by continuous shifting from supply driven paradigm to a more malleable demand-oriented strategy is addressed by development planners. Demand driven supply model dictates that all water users should participate in project planning, implementation, monitoring and evaluation and contribute to making decisions [16]. Some community water projects are working well in Latin America and Asia but the result in sub-Saharan Africa is the contrast of the projects in Latin America and Asia [9].

Before a project commences, the feasibility report should be produces to ascertain the effectiveness of the project. In this context, feasibility determines whether a given project is likely to succeed. It is one of the important measures that determine whether the project should move on or not [16]. Resource planning of water projects cannot be done without the feasibility report hence feasibility acts as the determinant in resource planning of projects. Feasibility basically assesses the following areas before the actual planning of the project; technical capability, budget, legality, risk, operational feasibility, and last but not list time [1].
Of significant references, several studies have been conducted with an aim of trying to expound on resonate of resource planning on successful completion of water projects. In a study conducted by [2] in Ebro river basin Spain and Tucson basin US Arizona on "Public Participation in Water Planning" the findings show that there was a deficiency of transformation capacity of public participation process on resources planning. According to the authors, holistic approach and political leadership were the main factors that resonate public participation in planning of water projects in USA Arizona and Ebro Spain.

A number of water projects globally utilize Specific Measurable Reliable and Timeline (SMART) as the only approach of evaluating whether the goals and plans put in motion are complete. The completeness of the project plan is arrived at when the goals and the plans are specific, measurable, achievable, realistic, and timely. SMART is a great foundation in project management since it fuses all the figures, facts, reports, and vital details just to mention a few that helps in water project resource planning. A specific goal for a project is the one that defines how success will look like. For example, you can set a goal that the project should be complete within a year, when the projects is completed within the specified time then the goal was achieved and the project was a success. In order to evaluate whether the set goals are measurable, they should contain qualitative or quantitative measurements that were formulated in the recent past and they are linked with those of the future [15].

Legislative Authorities also play a pivotal role in resource planning of water projects. They are basically the determining factor for resource planning since they provide financial support to water projects. Ideally Finance is one of the pillars of resource planning hence when legislative authority pumps a significant amount of fiancé to water projects then resource planning will be easier and more efficient. In a study conducted by [13] in Kenya his findings depicted those legislative authorities did not provide sufficient funds for water projects due to corruption and other underlying factors which in turn affects successful completion of water projects.

The inclusion of climate change in planning of water resources is vital in ensuring sustainable growth and development. A recent study in Polokwane town in South Africa, demonstrated the effects of incorporating climate in the planning of water resources.

Further, with the incorporation of climatic change in planning, water projects can easily plan for effective measures that will help combat water scarcity during draught season [5]. For resource planning to be successful, effective implementation of monitoring and evaluation should be ensured in every stage of the project. Ideally, monitoring is the science of counter checking progress against plan. Monitoring facilitates the documentation of progress, results, and experiences that will be used in future to make decisions and to draw anticipations. On the other hand, evaluation confines the obtained results from monitoring and in turn splits them to specific pieces of information that will be later used for project planning. 


\section{A. Resource-Based Theory}

Resource based theory is based on the economic muscle and the view of the organization as a collection of capabilities. It offers critical and fundamental insights of how organization with organized resources may enjoy significant financial performance [14]. Its main contribution is embedded in the notion of competitive advantage [6]. Several studies have defined resources, but can include money, manpower, machinery, and materials. Resourcebased theory suggests that organizations can engender sustainable competitive advantage through coining of unique resources and capabilities [7].

\section{RESEARCH Methodology}

This study employed a descriptive survey research design. The researcher used Descriptive and inferential statistics to analyze the data. The study targeted representative beneficiaries of water projects in Machakos County, Water Management committee members, Sub-county water officers and Machakos County Local Coordinators. The study population was 648 participants in water project. A sample size of 241 participants was obtained through purposive and simple random sampling procedures. To achieve the expected threshold for a sample size, the researchers drew the sample size using the formula suggested by [8] for calculating sample sizes hence arriving at 241. The data was collected using Questionnaires and $70.5 \%$ questionnaire return rate was obtained. Pilot testing was conducted among 24 participants of water projects and was not included in the main study. To measure the consistency of the research instrument reliability test was used and a coefficient of 0.82 was obtained. The study utilized both content and constructs validity to evaluate whether the research instrument measures what it intends to measure [12]. The study employed simple linear regression analysis to test Hypothesis.

\section{RESEARCH FINDINGS AND DISCUSSIONS}

\section{A. Resource Planning}

The researcher analysed the descriptive statistics of various statements and establish how resource planning as a panacea in successful completion of water projects. A fivepoint Likert scale rating was used and the findings demonstrated that all items in the Likert scale had a composite mean of 3.2382 and a standard deviation of 1.39635. The item 'Tender awards for the water projects followed the procurement process' had the highest (mean=3.9647 and $\mathrm{SD}=1.25408$ ). This was followed by 'Work schedules is shared to stakeholders by the project team' (mean=3.4647, S.D=1.35500), 'All stakeholders were involved during planning of the water project' (mean=3.1824, S.D=1.56013), 'Feasibility study is conducted by experienced project stakeholders' (mean=3.1588, S.D=1.51269), 'There is continuous monitoring of the water projects during implementation' (mean=3.0941, S.D=1.34229) and 'Legislative authorities increases statutory allocation for resource planning exercise' (mean=2.5647, S.D=1.35391).

Successful completion of water projects was the dependent variable in this study. Various statements were set to be answered by the respondents in order to measure the strength of this variable.

The results and the finding of this showed that there is a strong relationship between this independent variable and dependent variable. The statement that Tender awards for the water projects followed the procurement process was the most outstanding in relation to Successful completion of water projects. This finding was supported by [4] whose findings demonstrated that success of a project is characterized by completion of project on time, within the specified budget, within the anticipated quality and without unexpected cost escalation.

Table I shows that adjusted $\mathrm{R}^{2}$ is the coefficient of determination which indicates successful completion of water project varies with Resource Planning, from the table 1 , adjusted R-squared is 0.411 . This implies that about $41.1 \%$ of variation in Resource Planning is explained by variation on successful completion of water project while the rest are explained by the error term.

The variations of Resource Planning value influence Successful Completion of water project at 0.000 meaning that the overall model was significant.

The results of Table II shows that Resource Planning indicates that numerator df (1), denominator df (168). The results findings of the F-test show that the model had a good fit for the data. The F-Test $(\mathrm{F}=62.061, \mathrm{P}=0.000<0.05)$. The regression model is significant since $\mathrm{P}$ value $=0.000$ which is less than $5 \%$.

This provides a significant level of explanation of the relationship between dependent variable and independent variables. This implies that $95 \%$ chance that the relationship with the variable is not due to chance.

TABLE II: ANOVA

\begin{tabular}{ccccccc}
\hline \hline \multirow{2}{*}{ Model } & $\begin{array}{c}\text { Sum of } \\
\text { squares }\end{array}$ & df & $\begin{array}{c}\text { Mean } \\
\text { square }\end{array}$ & F & Sig. \\
\hline 1 & Regression & 1662.445 & 1 & 831.222 & 62.000 & .000 \\
& Residual & 2302.332 & 168 & 13.386 & & \\
& Total & 3964.777 & 169 & & & \\
\hline \hline
\end{tabular}

a. Dependent variable: Successful completion of water projects.

b. Predictors (Constant), Resource Planning.

TABLE III: COEFFICIENTS

\begin{tabular}{cccccc}
\hline \hline \multicolumn{2}{c}{ Unstandardized Coefficients } & \multicolumn{3}{c}{ Standardized Coefficients } \\
\hline Model & B & Std. Error & Beta & t & Sig \\
\hline 1 (Constant) & 10.006 & 1.120 & & 6.236 & .000 \\
Resource Planning & .415 & 0.57 & .410 & 5.401 & .000 \\
\hline \hline
\end{tabular}

a. Dependent Variable: Successful completion of water project.

TABLE I: MODEL SUMMARY

\begin{tabular}{|c|c|c|c|c|c|c|c|c|}
\hline \multirow[b]{2}{*}{ Model } & \multirow[b]{2}{*}{$\mathrm{R}$} & \multirow[b]{2}{*}{$\begin{array}{c}\mathrm{R} \\
\text { square }\end{array}$} & \multirow[b]{2}{*}{$\begin{array}{l}\text { Adjusted } \\
\mathrm{R} \text { square }\end{array}$} & \multirow[b]{2}{*}{$\begin{array}{l}\text { Std. Error of } \\
\text { the Estimate }\end{array}$} & \multicolumn{3}{|c|}{ Change statistics } & \multirow[b]{2}{*}{$\begin{array}{c}\text { Sig. F } \\
\text { Change }\end{array}$} \\
\hline & & & & & $\begin{array}{c}\mathrm{F} \\
\text { Change }\end{array}$ & df1 & df 2 & \\
\hline 1 & $.624^{\mathrm{a}}$ & .417 & 2.741 & .419 & 62.06 & 1 & 168 & .000 \\
\hline
\end{tabular}

a. Predictors: (Constant), Resource Planning.

Dependent: Successful Completion of Water Projects. 


$$
\left(\mathrm{Y}=10.006+0.415 \mathrm{X}_{1}+\epsilon\right)
$$

The findings depict that resource planning would lead to successful completion of water project by factor of 0.415 with $\mathrm{P}$ values of 0.000 . At $5 \%$ level of significance and $95 \%$ level of confidence this is statistically significant as the PValue is lower than 0.05 . It was further hypothesized that: Ho: There is no significance of Resource Planning as a panacea in successful completion of water projects in semiarid areas in Machakos County. The study therefore rejects the null hypothesis implying that there is significant influence of Resource Planning on Successful Completion of water project. On the basis of these statistics, the study concludes that there is significant positive relationship between of Resource Planning and Successful Completion of water project.

\section{CONCLUSION}

In conclusion, despite Resource Planning influences Successful completion of water project. In the light of study findings, it can be concluded that Feasibility study should be conducted by experienced project stakeholders in order to ensure successful completion of water projects. Additionally, all stakeholders should be involved during planning of the water project and there is need for Legislative Authorities to increase statutory allocation for resource planning exercise that would help enhance successful completion of water projects.

\section{RECOMMENDATIONS}

The study recommends that there is need for feasibility study to be conducted by experienced project stakeholders for better resource planning.

A further recommendation, there is need for legislative authorities to increase statutory allocation for resource planning exercise that would help enhance successful completion of water projects.

\section{REFERENCES}

[1] Ann, K. (2020). What Is a Feasibility Study in Project Management. Project Management Guide.

[2] Ballester, A. (2017). Public Participation in Water Planning in the Ebro River Basin (Spain) and Tucson Basin (U.S., Arizona): Impact on Water Policy and Adaptive Capacity Buildin. MDPI.

[3] Bro, C., Cow, i. C., \& Kampax, -K. (2018). Regional Water Master Plans for Iringa, Ruvuma and Mbeya Regions. Hydrogeology Vol 9. Ministry of Water for Tanzania.

[4] Choge and Muturi. (2014). Factors affecting adherence to cost estimates: A survey of construction projects of Kenya National Highways Authority. International Journal of Social Sciences and Entrepreneurship, vol. 1, pp. 689-705.

[5] Cullis, J. S. (2018). Incorporating climate change into water resources planning for the town of Polokwane, South Africa. Climatic Change, 437-456.

[6] Fricker, M. (2007). Epistemic Injustice: Power and the Ethics of Knowing. Oxford, United Kingdom:. Oxford University Press.

[7] Kay, j. (2015). On being stuck in the middleor good food costs less sainsbury's. British Journal of Management.

[8] Kothari, C. R. (2009). Research Methodology: Methods and Techniques. New Delhi: . New Age Publications.

[9] Lockwood and Smits . (2011). Supporting Rural Water Supply: Moving towards a service delivery approach. Warwickshire, UK: Practical Action Publishing Ltd.

[10] Lutz-Ley, A. (2020). Dialogic science-policy networks for water security governance in the arid Americas. sciencedirect.

[11] Mugenda \& Mugenda. (2009). Research Methods.Qualitative and Quantitative Approach. Nairobi: Acts Press.

[12] Mugenda, \& Mugenda. (2003). Research methods. Nairobi: Acts Press.

[13] Njogu, M. J. (2018). Influence of community participation on project performance of ruiri water projects, meru county, kenya. International Academic Journal of Information Sciences and Project Management.

[14] Nyangilo. (2012). An assessment of the organization structure and leadership effects on construction projects performance in Kenya.

[15] Parkway, M. (2015). SMART Planning: Defining Better Goals for your Business.

[16] PMI. (2017). Guide, P. M. B. O. K4th Edition. Newton Square, Pennsylvania, USA.

[17] Rakesh, Singh, \& Sharma. (2018). Water resources of India. Current Science Association, 794-811.

[18] UNICEF, \& WHO. (2012). Progress on Drinking water and Sanitation. New York: United Nations.

[19] Watt, A. (2020). Resource Planning. BC Campus.

[20] World Vision. (2020). Global water crisis: Facts, FAQs, and how to help. 